\title{
The Influence of Anton Chekhov on Samuel Beckett: Inaction and Investment of hope into Godot-like Figures in Three Sisters and Waiting for Godot
}

\author{
Samira Sasani \\ Parvin Ghasemi \\ Department of Foreign Languages and Linguistics, Faculty of Humanities and \\ Literature, Shiraz University, Eram Campus, Eram Street 7194684795, Shiraz, Iran \\ e-mail: samira.sasani21@yahoo.com \\ pghasemi54@gmail.com
}

\begin{abstract}
Anton Chekhov has been very much influential on modern drama, especially on the Theatre of the Absurd; however, not much work has been done on his influence on the absurdist playwrights. Considering Harold Bloom's definition of 'influence' — writing "much like" someone in the past - the seminal influence of Chekhov on Beckett is studied in this article. Chekhov in his plays, especially his major plays, very much like Beckett's waiting for Godot, portrays people who are passively waiting and investing their entire hope into Godot-like figures without taking any action. Thus, the sense of ennui, desperation and consequently disappointment of these characters originates from their unreasonable inaction, stagnancy and their passivity while waiting, rather than 'waiting for Godot figures'. This article tries to show the influence of Chekhov on Samuel Beckett, investigating the similarities in form, atmosphere and theme between Waiting for Godot, the paradigm of the Theatre of the Absurd, and Three Sisters, one of Chekhov's major plays.
\end{abstract}

Key words: Three Sisters, Waiting for Godot, passivity and inaction, passive investment of hope

Nothing is funnier than unhappiness, I grant you that. ...

it's the most comical thing in the world.

(Endgame)

Habit is a great deadener.

(Waiting for Godot) 
Anton Chekhov has been very much influential on modern drama, especially on absurdist drama. Chekhov, very much like absurdist playwrights, does not foreground plot but human's mood and situation, so action arises from character, rather than plot. Chekhov is known with his very technique of "indirect action" as David Magarshak in his book, Ckekhov the Dramatist names it, when he propels his plays through action taking place off stage. In addition to his technique, his themes and characterization is very much like the conventions of the Theatre of the Absurd; though not much work has been done on it. Martin Esslin in his book, The Theatre of the Absurd, for the first time calls Samuel Beckett and a number of other playwrights "absurdist" and counts some traits for this type of writing. Beckett has never acknowledged his debt to Chekhov, but when his plays are investigated, one can find the influence of Chekhov on Beckett (probably Beckett is unconscious about) and understand that his writing is very much like Anton Chekhov's. Based on Harold Bloom's idea about 'literary influence', 'influence' is not merely attributed to conscious or admitted influence, but based on his idea pronounced in his crucial texts-The Anxiety of Influence and his recently published book called The Anatomy of Influence (2011) - "writing much like" some one in the past is also considered as 'influence'.

Samuel Beckett in his play, Waiting for Godot, the paradigm of the Theatre of the Absurd, very much like Chekhov, delineates characters whose passivity and inaction is the source of the sense of ennui and desperation and ultimately their disappointment. The characters' disappointment and depression does not originate from the lack of opportunity but it is the characters themselves who provide the only major obstacle. That is why Chekhov calls his major plays comedy and not tragedy, likewise Nell in Endgame posits: "nothing is funnier than unhappiness, I grant you that. . . . it's the most comical thing in the world" (Beckett, 1956, p. 18). What is really comical in Chekhov and later on Beckett's plays is the characters' lack of action when it is much required. The only thing these characters are able to do is talking and waiting passively for meeting their ideals or Godot figures. So Godot, or waiting for Godot is not the cause of their boring lives, instead 'mere waiting' or their illogical passivity while waiting makes them disappointed and tired of living.

Chekhov is not an absurdist playwright but he paves the way for this kind of drama. Man, in the Theatre of the Absurd, is tired of his boring and 
monotonous life. For him, life has no reasonable outcome. This kind of drama, as Martin Esslin (1964) says: "strives to express its sense of the senselessness of the human condition and the inadequacy of the rational approach by the open abandonment of rational devices and discursive thought" (p. 17). In addition to the content, the form of these plays is different from the form of the well-made plays. The form also conveys the sense of repetition and tedium. These plays have the circular form; they end where they began and unlike well-made plays, the emphasis is not on the plot. "If a good play must have a cleverly constructed story, these [absurdist plays] have no story or plot", Esslin says (p. 15). These are some of the characteristics common in both Chekhov and Beckett's plays though, as it will be discussed later on, there are differences between Beckett and Chekhov, as well.

Like Vladimir and Estragon, nearly all of Chekhov's characters are passively waiting for their ideals and lament their desires without taking any action. Thus, speech substitutes for action, in these plays. So "the stylized theatre" as Vsevolod Meyerhold (1995) argues "avoids the 'mood' of Chekhovian theatre, which transforms acting into the passive experiencing of emotions" (p. 243). Mark Slonim (1966) also believes that "the monotony of routine is a law" of the existence of Chekhov's characters. "All are sick to death of their own emptiness of their words and gestures, but they resume them again and again exasperating regularity" (p. 63). David Ian Rabey (2003) argues:

From one perspective, Beckett has been associated with a development of the Chekhovian form which has dominated English dramatic realism from the Thirties to the present; specifically, its elegiac and nostalgic 'demonstration of how commonplace detail can be used to bring out the complexity and pathos of ordinary lives' and 'the almost unbearable sadness of time's effects upon them' (p. 48).

In Three Sisters, Chekhov (1956) delineates a situation very much like Waiting for Godot. The main characters, Olga, Masha, and Irina are vehemently waiting for going to Moscow. Moscow, for them, is the promised land, Utopia, the land of hope, desire and happiness. As Irina says; "there's nothing in the world better than Moscow" (p. 203). They desire to resort to Moscow from their repeatedly boring lives, their depression and disappointment. Moscow plays the main role of Godot-like 
figure in the play. Although, Normand Berlin (1981) in his book The Secret Cause: A Discussion of Tragedy calls Chekhov's Three Sisters, Waiting for Moscow (p. 109), it should be emphasized here that Moscow is not the Godot-figure just because it is the unfulfilled desire of the characters who ardently desire it, but the similarity of the most of the characters of the play to Vladimir and Estragon also reinforces this very notion towards the play.

Going to Moscow is a dream growing stronger every day for these sisters. In addition to Moscow, there is another thing these three sisters are dreaming about; though, the very base of all their wishes is in Moscow and all of these wishes will be accomplished there. Seeing Andrei as a professor teaching successfully in Moscow is another thing they are pinning their hopes on. The concept of waiting is at the core of the play, whether for Godot, Andrei or whatsoever. In other words, the play turns around passive waiting, talking, stagnancy and inaction. It is about waiting for what the characters assume as the ideal to happen. The characters are just talking and waiting to get their ideal without stepping towards it, without doing anything. All they do is investment of hope into others and better life in future, not into their capabilities. Not being able to act, they get bored and desperate and consequently not meeting their ideals, they get much more disappointed.

Olga, the oldest sister, complains about her undesirable situation as a high school teacher, about her health growing weaker, going out of her day by day, drop by drop. She passionately calls for her very ideal, for turning back to Moscow. She is twenty eight years old and not married. At this age, she thinks that she is old and that she has wasted her life teaching all these years. Later on, advising Irina to marry Tusenbach, Olga tells her that she is not happy of being single, and that she would marry even an old man. Masha and Irina, respectively twenty five and twenty years old, like Olga, helplessly bear the heavy loan of dissatisfaction of the tedious life. Not only these three sisters but most of the characters are complaining about their lifeless lives while they believe that they should wait, since the future would be better.

The whole play is the story of people who are tired of their boring lives, so they resort to dreaming about their desires. These three sisters, their brother, and the officers are all dreaming about better life in future. The whole play is summarized in speeches rather than actions. FischerLichte (2002) argues: "nearly all the characters in Three Sisters are lonely, 
but they do not withdraw into silence because of it - quite the contrary, because they are lonely, they talk. They talk about daily things or the future of mankind, they talk for the sake of talking, for only talk can take away their feelings of loneliness" (p. 262). Investing in future and not being able to benefit from now and here, they are wasting their lives. Even the educated characters are not happy and cannot benefit from their education and knowledge, so their education seems totally absurd. Sometimes, these characters are even much more disappointed and desperate than simply less educated or less intellectual people, such as servants who much more enjoy life without thinking and philosophizing, people who just work and enjoy working. In Three Sisters, Olga, Masha, and Irina are educated women, they know the French, German and English languages but as they say it is totally useless. Vershinin acknowledges: "there is not and can't be a town so boring and dull that a clever, educated person would be unnecessary in it" (Chekhov, 1956, p. 153).

What is very much ridiculous in Chekhov and later on in Beckett's plays is that the people are passively waiting for better life. Vershinin believes that though they are not happy in this life, nothing can be done about it; he argues that the only thing they are able to do is waiting. He tells Masha: 'after two or three hundred years life on earth will be unimaginably beautiful, and wonderful", and that "man needs such a life, and if it is not here yet, he must anticipate it, wait, dream of it" (Chekhov, 1956, p. 154). In response Tusenbach admits his sayings about waiting for wonderful future but he adds that to reach that point, they must work and prepare themselves at present and should do something for it. Kulygin, Masha's husband, also confirms Tusenbach's sayings, when he reasons that the Romans were healthy since they knew how to work and how to rest.

Masha, like Uncle vanya who passively wait for his ideal and ultimately gets disillusioned of Professor Serebriakoff, gets disillusioned of her husband, Kulygin, of what she had previously considered as the ideal. Masha thinks she suffers, since her husband is a teacher and is "not fine enough, gentle enough". But it is the problem of all the people in the play. Vershininn assures Masha that this sense of boredom of life is something common among them whether they are civilian or military. He assumes that this problem arises from their passivity and stagnancy; he finds the roots of this problem in just philosophizing and thinking and not being able to act and make dreams feasible. 
Philosophizing of these people is very much like Lucky's mechanical thinking in Waiting for Godot. Philosophizing is something mechanically done by these people throughout the play for the sake of filling up time:

Vershinin: If they are not giving us any tea, let's at least philosophize. Tusenbach: Yes, let's. What about?

Vershinin: What about? Let's dream . . . for example, of the life that will come after us in two or three hundred years. (p. 171)

Vershinin assumes that the only cause of living this boring life is hope for future when "a new happy life will come". He philosophizes that the cause of being, of present existence is in future, in two or three hundred, even thousand years later. He, like many other characters of Chekhov, cannot find any meaning for his current life, so he helplessly resorts to future. One can feel the emptiness of Vershinin's wishes for future, considering his irresponsibility and his recklessness to the present and to what he can do to make his current life better. Vershinin believes that happiness is the lot of his remote descendents, the descendents of his descendents. As he himself asserts: "happiness we have not and it does not exist, we only long for it" (p. 176).

Andrei, like his sisters, is living in his dreams. He passes his time idly dreaming a phony future. Each night, he dreams that he is a professor at Moscow University, a famous scholar whom the Russian land is proud of. Becoming a professor at Moscow University is not only his ideal but the very desire of his sisters, as well. Together with Moscow, these three sisters invest their hopes into Andrei, another Godot-figure. Andrei, like Professor Serebriakof in Uncle Vanya, totally shatters his sisters' hopes and dreams. $\mathrm{He}$ is the secretary of the District Board and as he says the very most he can hope for is to be a member of the District Board. Andrei loses two hundred roubles at playing cards, so he's mortgaged the house belonging to four of them to the bank without asking his sisters' permissions.

Masha in act IV of the play disappointedly asserts: "all our hopes gone.... Once upon a time, thousands of people were hoisting a bell, a lot of effort and money were spent, and then suddenly it fell and broke. Suddenly for neither one reason nor another. The same with Andrei" (p. 210). Andrei's wife, Natasha, the opportunist, grabbles all the money belonging to them and rules over them. As a "death figure"-Anthony S. Abbott divides Chekhov's characters to "life" and "death" figures- 
Natasha is completely different from others in the play; she is not that much lethargic and languid. Her affair with Protopopov is the subject of the whole town's talking, but it is only Andrei who knows and sees nothing. Andrei is a very ridiculous character engaging himself with playing the violin and not caring about anything. His excessive inaction is shown at the time of catastrophe when fire is everywhere; when every one rushes towards it to extinguish it - however it occurred off stage — but he, in his dreams of better life in future passively sits and without paying the least attention, plays the violin.

The characters' passivity is the cause of all their failures. Even if they work, it is ridiculously mechanical and is not the source of improvement for them, conversely it gradually weakens them to the extent that they lose all their abilities, and all their energies mentally and physically. Irina, the youngest sister, for instance, notes that she is gradually forgetting Italian. Very disappointed of everything, of his brother, of going to Moscow to meet her ideal beloved, she says: 'I'm forgetting everything, every day forgetting, and life slips away and will never return, never, we'll never go to Moscow. .. . I can see we'll never go", "no satisfaction of any kind, and time is passing, and it all seems to be moving away from any real, beautiful life all moving away farther and farther into some abyss.... I'm in despair, and how I'm alive, how it is I haven't killed myself, I can't understand. .." (p. 198).

It is as if, like Waiting for Godot, there is nothing to do except waiting, or that they are able to do nothing but passive waiting. Either, they consciously invest their entire hope into a person, waiting vainly to meet their ideals in him, like Andrei; or they invest their hope into something which they don't do anything for achieving, like Moscow. Later on Beckett, much like Chekhov, delineates inaction and stagnancy in his plays; however, his depiction is much more exaggerated. In Waiting for Godot, Vladimir and Estragon several times decide to go and leave the place but they don't, that is very much like not going to Moscow or not performing any meaningful action such as working they repeatedly refer to as the only remedy. In Waiting for Godot, although Vladimir and Estragon know that their investment in Godot is not that much reasonable- like the sisters' investment of hope into Andrei- they continue waiting for him, since "there is nothing else to do", or because the only thing they are able to do is waiting. 
In Chekhov and later on Beckett's plays, when inertia, ennui, desperation and consequently disappointment reaches to the highest level, the characters doubts about the meaning of life, about their existence and sometimes decide to commit suicide. Tchebutykin, the physician, philosophizing a lot, gets totally disappointed. Forgetting how to practice medicine, and no longer being able to cure people, he blames himself for killing a sick woman because of his inability. He doesn't remember anything, to the extent that he doubts his existence and thinks that he is not a man but only gives the appearance of having hands and legs and a head. Vershinin's wife is also very much hopeless. Taking poison, several times, she tries to commit suicide, but each time she fails to fulfill it. Enervation and inertia is seen everywhere in the play; no sign of life and liveliness is felt among the characters; it's as if everybody is dead to the world.

Although, Andrei and his three sisters never decide to commit suicide, they do nothing for achieving their ideal, either. They passively continue living their monotonous lives while disappointedly wait for their Godotfigure, Moscow. Irina, for instance, had decided to go to Moscow and find her beloved there but now she unwillingly accepts to marry Tusenbach; though she doesn't love him. But again, the day of wedding, she faces failure when Solyony who's been in love with her decides to challenge Tusenbach to a duel in which Tusenbach is killed. Irina passively does nothing to prevent Tusenbach of taking part in the duel. Olga, like her sister, very passively accepts to be a head-mistress of the high school she is working in; though she knows that becoming head-mistress and getting busier is equal to forgetting about going to Moscow. Surrendering to the conditions and not taking any action is the very trait of Chekhov's characters. Rollyson (2005) assumes that many of the characters in Chekhov's plays are absurd, "their concerns are ridiculous, and the detached observer must confess that they are silly" (p. 157).

All of the people are waiting for Godot who is the harbinger of change and happiness; but what makes their lives boring, is not Godot itself or waiting for Godot-like figures; instead while waiting, or how they wait while waiting is troublesome. Therefore, very much like Waiting for Godot, passive waiting or in other words "only waiting" since there is nothing else to do but waiting, or since they are not able to do anything except waiting is the cause of the sense of ennui and desperation in the plays of Chekhov and later on Samuel Beckett. Andrei is passively waiting for a vague future in which he and his children are freed from idleness but 
he doesn't consider his role and responsibility for this fortunate change. So as Gottlieb (2000a) argues, although, "the sad comicality of every day life" is the subject of Chekhov's plays, Chekhov treats it with a strong dose of comedy or a sense of proportion blended with the hope of a better life in future (p. 233).

Though, totally exhausted from the present life, the characters have only one choice, as Masha says, they "must live". Irina also confirms: "they must live" and "must work, only work" (Chekhov, 1956, p. 222). Working has two meanings in Chekhov's plays; when it is recommended at the time of extreme exhaustion and hopelessness, like here, it is exactly what Chekhov often recommends but it is never put into action by the characters and, very much like Vladimir and Estragon's decision to move, remains just as a suggestion leading to inaction. The other meaning of it is exactly what the hopeless characters are helplessly able to do mechanically and habitually to fill up time and as it is deduced in Chekhov's plays, this kind of working squeezes the last drops of liveliness out of the characters and is identical with passing time idly.

Not knowing the reason of living, they, absurdly, must live. They must live and dream of bright future full of happiness. If they knew the reason of living, their lives would be more meaningful, even their waiting would be reasonable and will be surely accompanied with the joy of knowing the meaning of life. "If we only knew, if we only knew", Olga deplores at the end of the play. Philosophizing about life, Olga mournfully acknowledges that they know nothing of why they live and why they suffer. So, the play ends where it began. Very similar to the beginning of the play, unaware of the philosophy of life, they absurdly bear the heavy burden of life, and passively wait for a Godot-like figure who would save them from the hell they are living in.

Doing nothing, waiting passively for a Godot-like figure, and getting busy with philosophical issues, the vast majority of Chekhov's characters go under the heavy burden of existential despair. Therefore, the very cause of these characters' disappointment is rooted in their mere thinking, or in philosophizing about life without doing any action. Later on, Beckett very much like Chekhov, emphasizing characters' passivity and inaction, creates the same sense in his works especially in his well-known absurdist play, Waiting for Godot, the paradigm of the Theatre of the Absurd.

Waiting for Godot starts with Estragon saying: "Nothing to be done" (Beckett, 1954, p. 7). Very much like Chekhov's plays there is nothing to 
be done; the characters are wasting their lives waiting for ideals which are never met, or for desires which are never fulfilled because of their very traits. Ennui, desperation, inaction, boredom, stagnancy and consequently hopelessness are the very characteristics of Chekhov and later on Beckett's characters; though, there is a difference between Chekhov and Beckett's portrayal. Chekhov illuminates human's mood, he demonstrates human's passivity, and his inaction; whereas he endlessly tries to convey that we should improve our lives ourselves, and that there is much to be done. Gottlieb argues: "the philosophical core of his comedy is that of a doctor who knows there is a cure - yet everyone is sitting and wailing about the disease" (p. 131). Beckett's plays, on the other hand, are the exaggerated form of Chekhov's comically disappointing plays. Chekhov's plays, especially his major plays are about passive waiting and disappointment, while Beckett's Waiting for Godot is not about waiting, it is the very incarnation of disappointment and passive waiting, itself. "Waiting for Godot does not tell a story; it explores a static situation" (Esslin, 1964, p. 33). Michael Y. Bennett (2009) admits that "Esslin was correct in that the playwrights of the Theatre of the Absurd do not argue whether the world is absurd or not, and they certainly do not try to define this sense of absurdity: they merely present it as such" (p. 19).

Vladimir and Estragon are both waiting for their ideal, Godot. They have nothing to do except waiting and investing all their hopes in Godot, who will not come today but surely tomorrow. While waiting, they are jabbering nonsense to pass time. They are tired and hopeless of waiting for Godot. Like Chekhov's major plays, the characters' dissatisfaction and boredom together with their inaction is the source of comedy in this tragicomic play. Several times they decide not to wait and leave the boring situation but their decision without any logical purpose leads to comic and illogical inaction. They are not happy creatures; several times they point to this fact that they are bored and unhappy and that they should pretend of being happy, till Godot comes. Godot is the promised savior; thus they will wait till Godot comes and save them from the hell they are living in. They do not feel safe to be alone or to be silent; like passive characters in Three Sisters, they try to be with each other and to chat all the time to feel safe in this hell, before visiting their savior.

What they say about the thieves quoted in Bible, allegorically, is very telling of their situation. Vladimir tells Estragon: "One of the thieves was saved. It's a reasonable percentage" (Beckett, 1954, p. 8). They are not 
sure of visiting Godot, but for them it is worth waiting for him. They are not sure of Godot's name; of the time he promised them to come; Vladimir hesitantly says: "He said Saturday. I think" (p. 10). They are sure of nothing; even they are not sure of the place they should wait for seeing him. It is really comic that they are ridiculously investing their entire hope in Godot whom they are totally uncertain about his coming. As Richard Keller Simon (1987) asserts, "many critics explain Beckett's work as a form of philosophically and theologically complex comedy, one that affirmed the values of humor, laughter and mockery against suffering and despair" (p. 111).

Not visiting Godot after passively waiting for a long time, Vladimir and Estragon get tired and totally hopeless of seeing him and decide to hang themselves. Martin Esslin (1964) believes that, in their view, with this decision "the boredom of living is replaced by the suffering of being" ( $\mathrm{p}$. 44). But very much like Chekhov's characters their decision comically doesn't lead to action. As they confess, "it's safer" for them not to do anything and unreasonably wait for Godot (Beckett, 1954, p. 12). Like many of Chekhov's characters who do not change even after their understanding of the emptiness of their hope; Vladimir and Estragon do not change throughout the play.

Time goes on, everything changes but not Vladimir and Estragon. Their unchanged and static situation, like Chekhov's characters, is because of their passivity, and not the lack of opportunity. Vladimir and Estragon demonstrate the excessive degree of passivity. Although thinking is the minimum level of meaningful action, they even don't like to think. They believe: "we're in no danger of thinking anymore . . . Thinking is not the worst. ... What is terrible is to have thought" (p. 41).

Pozzo and Lucky are other creatures of this wasteland passing their time in vain. Were they in Vladimir and Estragon's shoes, they would behave the same. When Vladimir, bored of waiting, contests over their endlessly tiresome situation, Pozzo encourages him to continue waiting for Godot. Pozzo's strategy to fill up time while waiting is very similar to Vladimir and Estragon. Like them, he mistakenly takes talking and laughing for true action. Inability for distinguishing action from inaction is also the very striking trait of Chekhov's characters. They lament their desires to perform actions but they ultimately do nothing; not able to act, they are also "unable to determine what qualifies as an action" (Bartlett, 2005, p. 1). 
All of the characters behave mechanically just to fill up time and get to the end of waiting, very much like the tree sisters who are working mechanically to pass time, to entertain themselves with working till they get to the end of the boring life. As Estragon says, "Nothing happens, nobody comes, no body goes, it's awful!" (Beckett, 1958, p. 27). Vladimir and Estragon are entertaining themselves babbling nonsense and also thinking about nonsense. They are wondering why Lucky does not put down his bags which he foolishly keeps holding all the time or why he puts them down while dancing. Whatever they do is for the sake of passing time and not truly a meaningful action.

They are doomed to waiting but what makes the situation intolerable is their passivity and stagnancy. Their idleness, sometimes, makes them forget why and for whom they have waited. What Beckett delineates is the condition of people who are passively waiting for something; Beckett shows waiting itself and what happens while waiting, while his emphasis is on how people may absurdly pass time waiting for their ideals. Therefore, it is their passivity which is the source of all their sufferings, boredom and disappointment and not simply "waiting for the ideal". In Waiting for Godot, meeting Godot is the ultimate goal, but while waiting, Godot's message is not that much important for Vladimir and Estragon. All they do is passive waiting; or in other words waiting without accepting their responsibilities, which is very much like Chekhov's Three Sisters in which almost all the characters are passively waiting for meeting their ideals.

The boy, in act I, tells them "Mr. Godot told me to tell you he won't come this evening but surly to-morrow" (Beckett, 1954, p. 33) and asks them to give him a message if they have any for Mr. Godot. Like Tchebutykin in Three Sisters who is not sure about his existence, Vladimir and Estragon simply asks him to tell Mr. Godot that he saw them. They don't know what to do; Vladimir acknowledges that they have nothing more to do and Estragon assures him that "nor anywhere else" (p. 34). Though, they decide to go and come back tomorrow; though, they both know that it is no longer reasonable to wait, as the stage direction reads, "they do not move", since they have nothing else to do but waiting.

No sign of change is seen in Vladimir and Estragon in the second act while it seems that much time has passed and the bare tree has leaves now. So, their second effort to commit suicide tying the rope to the branches of the live tree is paradoxical: "It is paradoxical that the tramps toyed with the idea of hanging themselves on the only living thing around - the tree - but 
the living tree would not accept them. This is a clear victory for life. Thus, the atmosphere may be gloomy, but the gloom itself does engender light" (Uwah, 1989, p. 128). Everything is dynamic around them, time flows, the tree grows leaves but they are static, and not in reasonable harmony with other things. How is it possible that they hope change for better life in future without changing themselves, and their situation; without taking any action? This is a crucial question in both Chekhov and Beckett's plays.

To pass time they decide to contradict each other, to ask each other questions leading nowhere. They both are aware of their passivity and boring lives; they are aware that whatever they label as "doing" is nothing but jabbering and nonsense. Asking each other of what they did the day before, both declare that they did nothing and passed time in vain. In the second act of the play, they are much more worn out of waiting for Godot who will come surly tomorrow. They are even tired of breathing or in other words of being. Waiting for a long time, and more disappointed than before, they try to pass time more ludicrously; this is what Vladimir emphasizes: "how time flies when one has fun!" (Beckett, 1954, p. 49). In this act, what helps them pass time is playing with words. They sing, repeat words and sentences incessantly, they make fun of words, they play the role of Pozzo and Lucky and also play with sentences. Another strategy they employ for passing time is dreaming. Vladimir and Estragon resort to dreaming to escape from their present dissatisfactory, dull and smothering situation. Estragon tells Vladimir that he was dreaming that he was happy; happiness is the thing they totally lack in their lives and, as Beckett believes, nothing is funnier than the lack of it.

The second coming of Pozzo who is heartbreakingly in need of help to get up, makes a new ray of hope in Vladimir and Estragon to do something while they have chance. But again, their decision to act leads to inaction. After babbling for a long time about their tedious life and about the repeated story of Cain and Able, they again become aware of Pozzo and his nonstop crying for help, who is very much in need of their help to get up.

After helping Pozzo, the topic of their discussion changes to another fruitless one concerning time and place; it is again nonsense, since both time and place are indescribable for them. Pozzo who is blind now asks them about the place, Vladimir responds that it is indescribable and that "it's like nothing" (p. 55). Their ignorance of time and place reinforces the passivity and inaction of these characters and much more highlights 
Beckett's portrayal of "passive waiting" rather than merely "waiting for, Godot".

The second coming of the boy who does not remember Vladimir and Estragon and on the other hand with the repeated message that Godot won't come today but surely tomorrow puts the worn out characters on the verge of committing suicide for the second time. But again their decision to act comically leads to inaction because these passive characters don't have enough rope for committing suicide. So, Vladimir postpones it to tomorrow, unless Godot comes; and if he comes they will be saved. They decide to leave and come back tomorrow; both agree but again as the stage direction reads, they do not move. What Anders (1965) says about Vladimir and Estragon's philosophy of living is very much similar to the philosophy of most of Chekhov's characters, he discusses: "we have no more to expect, therefore we shall not remain" (p. 143) is not what is attributed to Vladimir and Estragon, on the other hand they believe: "we remain, therefore we must be waiting for something" (Beckett, 1954, p. 143). In other words they remain, or as Olga and Masha say in Three Sisters, they "must live" since there is nothing else to do, or waiting is the only thing they can do.

Thus, Beckett very much like Chekhov demonstrates human's passivity; though the cause of passivity is different and consequently it leads to different outcomes. Chekhov believes in bright future and proposes zealous working as the remedy curing the malignant disease of passive characters' absurd lives, while Beckett offers no suggestion. Moreover, Chekhov's drama is much closer to reality than Beckett's. Chekhov, Gottlieb (2000b) posits, "illuminates and demonstrates human absurdity but in an essentially realistic context" (p. 237). However, in Beckett's Waiting for Godot, very much like Chekhov's major plays, passivity and inaction or in other words "waiting passively for Godot-like figures" is the main theme of the play which leads to ultimate disappointment. Beckett, like Chekhov dose not foreground plot but delineates man's desperate mood and situation. What Chekhov creates is "about passive waiting" while what Beckett creates is "passive waiting" itself. 


\section{REFERENCES}

Anders, G. (1965). Being without time: On Beckett's play Waiting for Godot. In M. Esslin (Ed.), Samuel Beckett: A collection of critical essays (pp. 140-152). New Jersey: Prentice-Hall, Inc.

Bartlett, J. (2005). Freedom and self-knowledge in the dramatic works of Anton Chekhov. (Unpublished Master's thesis). University of Missouri, Colombia.

Beckett, S. (1954). Waiting for Godot. New York: Grove Press.

Beckett, S. (1958). Endgame. New York: Grove Press.

Bennett, M.Y. (2009). Reassessing the theatre of the absurd: Parabolic drama and the question of absurdity. (Unpublished doctoral dissertation). University of Massachusetts, Amherst.

Berlin, N. (1981). A secret cause: A discussion of tragedy. Amherst: University of Massachusetts Press.

Chekhov, A. (1956). Best plays by Chekhov: The sea gull, Uncle Vanya, the three Sisters, the cherry orchard (S. Young, Trans.). New York: The Modern Library.

Esslin, M. (1964). The theatre of the absurd. London: Butler and Tanner Ltd.

Fischer-Lichte, E. (2002). History of European drama and theatre (J. Riley, Trans.). New York: Routledge.

Gottlieb, V. (2000a). Chekhov's one-act plays and the full-length plays. In V. Gottlieb and P. Allain (Eds.), The Cambridge companion to Chekhov (pp. 5770). Cambridge: Cambridge University Press.

Gottlieb, V. (2000b). Chekhov's comedy. In V. Gottlieb and P. Allain (Eds.), The Cambridge companion to Chekhov (pp. 228-239). Cambridge: Cambridge University Press.

Meyerhold, V. (1995). The stylized theatre. In R. Drain (Ed.), A twenty-century theatre: A sourcebook (pp. 243-245). New York: Rutledge.

Rabey, D.I. (2003). English drama since 1940. London: Pearson Education Limited.

Rollyson, C. (Ed.). (2005). Notable playwrights. Pasadena: SALEM Press, INC.

Simon, R. K. (1987). Beckett, comedy and the critics. In R. Cohn (Ed.), Beckett: Waiting for Godot: A selection of critical essays (pp. 111-114). London: Macmilan Press LTD.

Slonim, M. (1966). From Chekhov to the revolution: Russian literature 1900-1917. New York: Oxford University Press.

Uwah, G. O. (1989). Pirandellism and Samuel Beckett's plays. Potomac: Scripta Humanistica. 